\title{
ANALISIS POTENSI PENGEMBANGAN PERTANIAN ORGANIK \\ DALAM UPAYA PENINGKATAN PENDAPATAN PETANI \\ (Studi Kasus Pertanian Rakyat di Kecamatan Maro Sebo \\ Kabupaten Muaro Jambi)
}

\author{
Siti Aminah \\ *Dosen Fakultas Ekonomi Dan Bisnis Program Studi EP Universitas Jambi \\ Kampus Pinang Masak Jalan Raya Jambi - Ma.Bulian Km. 15 \\ Mendalo Darat Jambi
}

\begin{abstract}
Skyrocketing demand for organic agricultural products (without using chemicals), during these last few months because consumers are aware and selective top-qualityhealth products of agriculture. Agricultural product demand being high is vegetables, rice, fruit, spices, coffee and tea. Organic gardening tends to be more environmentally friendly because of the nature of the specific local. Ideally we strive to build plantations (at least the pilot orchards) organic. For the potential feasibility of agricultural development efforts on Agriculture organic food crops in Maro Sebo. To assess the feasibility of the venture with the pattern of organic farming tools used instruments namely Merchantibility Loss - Profit, Return Cost Ratio (R/C). Benefit Cost Ratio, The Break Event Point (BEP). The feasibility analysis of effort three commodities to agricultural businesses, namely rice, maize and chilli was able to provide considerable benefits for farmers.
\end{abstract}

Keyword: organic farming, farmers' income

\section{PENDAHULUAN}

Sektor pertanian di Indonesia merupakan sektor utama yang berperan terhadap perekonomian. Di samping itu negara Indonesia dikenal sebagai negara agraris. Mengingat sebagian besar rakyat Indonesia bermata pencaharian sebagai petani sudah sepantasnya sektor ini mendapatkan perhatian khusus pemerintah dalam upaya membangun kehidupan bangsa yang lebih baik di masa mendatang dengan mewujudkan suatu sektor pertanian yang kuat dan efektif dengan menerapkan aspek efisiensi dalam setiap usaha pertanian.

Pembangunan pertanian semestinya diarahkan pada pembangunan pertanian yang bertujuan untuk mampu mewujudkan ketahanan pangan nasional dalam upaya pemenuhan kebutuhan masyarakat secara keseluruhan dengan berorientasi bisnis bukan pertanian subsisten. Disamping itu petani harus mampu merespon perubahan selera konsumen seiring dengan besarnya perhatian terhadap standar kesehatan dari produk pertanian. Dengan kata lain memperhatikan aspek permintaan pasar, baik pasar lokal maupun pasar global.

Perkembangan permintaan produk pertanian dengan pola pertanian organik tersebut tentunya membuka peluang usaha baru bagi petani untuk meningkatkan diversifikasi hasil produk yang ditawarkan pada konsumen.

Perkembangan pembangunan pertanian pada tataran global dan nasional sepertinya tidak diikuti dengan upaya kongkrit dari stakeholders yang terlibat di bidang pertanian terutama yang terjadi di daerah. Pemerintah, 
pelaku usaha dan masyarakat sendiri seakan tidak terlalu peduli akan perkembangan perubahan permintaan pasar tersebut. Hal ini cukup merisaukan karena pada masa yang akan datang standarisasi produk pertanian akan makin ketat dan harus dijawab dengan keseriusan pengambil kebijakan dalam memberikan arahan berbagai program pembangunan pertanian.

Secara administratif kabupaten Muaro Jambi terdiri dari 11 kecamatan dan 5 kelurahan, 150 desa dan 7 Unit Pemukiman Transmigrasi (UPT). Kecamatan Maro Sebo terdiri dari 11 desa dan 1 kelurahan.

Pada kabupaten Muaro Jambi kontribusi sektor pertanian terhadap PDRB cukup dominan. Hal ini cukup beralasan karena dilihat dari potensi sumberdaya pertanian seperti luas lahan dan daerah yang merupakan dataran rendah sangat mendukung usaha bidang pertanian.

Pembangunan pertanian di kabupaten Muaro Jambi khususnya di kecamatan Maro Sebo masih mengembangkan pola konvensional dan sangat tergantung pada pupuk dan pestisida anorganik (kimiawi). Belum adanya respon terhadap pola pertanian organik dapat disebabkan karena belum adanya sosialisasi pemerintah terhadap pertanian organik secara komprehensif, ketidaktahuan masyarakat tentang keuntungan sistem pertanian organik atau dapat pula karena belum adanya petani yang menggunakan pupuk dan pestisida organik yang berhasil sehingga dapat menjadi bahan percontohan bagi petani lainnya.

Sehubungan dengan uraian sebelumnya maka peneliti tertarik untuk menganalisis tentang Potensi Pengembangan Pertanian Organik dalam Upaya Peningkatan Pendapatan Petani (Studi Kasus Pertanian Rakyat di Kecamatan Maro Sebo Kabupaten Muaro Jambi).

Tujuan dari penelitian ini adalah : a) Mengetahui pola pertanian rakyat di kecamatan Maro Sebo kabupaten Muaro Jambi khususnya pertanian tanaman pangan. b) Mengkaji potensi kelayakan usaha pengembangan pertanian organik pada pertanian tanaman pangan di kecamatan Maro Sebo.

\section{TINJAUAN PUSTAKA}

\section{Pembangunan Sektor Pertanian}

Strategi kebijakan dalam pembangunan pertanian diperlukan baik secara makro maupun mikro. Pada skala mikro dengan cara membangun pertanian dari aspek input sector, pengolahan hasil maupun output sector yaitu pemasarannya. Sedangkan secara makro lebih pada tataran kebijakan pemerintah secara makro yang ditujukan untuk membangun pertanian secara nasional, diantaranya dengan terus berupaya menciptakan iklim usaha yang kondusif melalui kebijakan pemerintah di bidang pertanian.

Peningkatan produktivitas sektor pertanian juga meningkatkan taraf hidup dan kesejahteraan sebagian besar rakyat yang pada umumnya bergerak di sektor pertanian yang diharapkan mampu meningkatkan pajak dan tabungan sehingga dapat membantu pembiayaan anggaran pemerintah dari sumber domestik.

\section{Teori Produksi Pertanian}

Menurut Sukartawi (1990) faktor produksi pertanian adalah semua pengorbanan yang diberikan pada tanaman sehingga mampu tumbuh dan 
menghasilkan dengan baik. Muryarto (1989) membagi faktor produksi dalam pertanian menjadi modal, tenaga kerja dan tanah. Sedangkan Hernanto (1989) menyatakan ada empat unsur pokok pada usaha tani yaitu tanah, tenaga kerja, modal dan pengolahan.

\section{Pendapatan Usaha Tani}

Dalam menganalisa keuntungan dalam usaha pertanian, keuntungan $(\pi)$ adalah selisih antara penerimaan total (TR) dan biaya (TC). Total revenue diperoleh dari mengalikan antara output produksi (Q) dengan tingkat harga (P). Biaya ini dalam kenyataan dapat diklasifikasikan menjadi 2 yaitu biaya tetap (FC) seperti sewa tanah, pembelian alat pertanian dan biaya tidak tetap (VC) seperti biaya yang diperlukan untuk membeli bibit, pupuk, obat-obatan, pembayaran tenaga kerja.

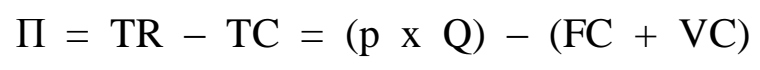

\section{Pertanian Organik}

Jaringan Kerja Pertanian Organik Indonesia (Jaker PO Indonesia) mengartikan bahwa pertanian organik merupakan pertanian yang bekerja sama dengan alam, menghayati dan menghargai prinsip-prinsip yang bekerja di alam yang telah menghidupi segala makhluk hidup berjuta-juta tahun lamanya (www.jakerpo.org). Adapun prinsip-prinsip umum dan teknis yang merupakan standar minimal pertanian organik perlu diterapkan antara lain :

a. Prinsip Ekologis

Prinsip ekologis dalam pengembangan pertanian organik adalah pedoman yang didasarkan pada hubungan antara organisme dengan alam sekitarnya dan hubungan antara organisme itu sendiri secara seimbang.

b. Prinsip Teknis Produksi dan Pengolahan

Prinsip Teknis Produksi dan Pengolahan yang dipakai dalam pengembangan pertanian organik yang ramah lingkungan.

c. Prinsip Ekonomi dan Sosial

Prinsip ekonomi dan sosial dimaksudkan sebagai aspek non teknis dan ekologis dalam pengembangan pertanian organik yang merupakan bagian integral dari usaha pertanian organik yang bertujuan menjamin kelangsungan hidup petani.

Pertanian organik adalah pertanian yang berangkat dari paradigma holistik dalam memandang alam semesta. Tradisi lama atau kearifan lokal dirujuk dalam pertanian organik karena adanya paradigma holistik yang menghargai keselarasan alam, dibandingkan karena teknologinya.

Organisasi internasional yang mengeluarkan standar dan peraturan untuk proses produksi organik yaitu International Federation of Organic Agriculture Movement (IFOAM) dan The Codex Alimentarius Commission $(C A C)$. IFOAM adalah badan internasional yang mendukung perkembangan sistem pertanian organik pada tingkat lokal dan regional, salah satu aktivitasnya adalah membuat standar dasar pertanian organik. Standar ini memberikan kerangka dasar ke seluruh dunia untuk menyusun program sertifikasi sesuai standar nasional dan regional. Standar dasar IFOAM juga disusun untuk dasar bekerjanya program akreditasi. Sedangkan CAC adalah badan hasil kerja sama FAO-WHO untuk standar 
pangan. Program standar pangan meliputi produksi, pengolahan, pelabelan dan pemasaran pangan hasil produk organik. CAC menjadi panduan internasional mengenai informasi dan perlindungan konsumen dari produk pangan hasil pertanian organik. CAC juga mendorong pemerintah untuk membuat peraturan di dalam negaranya, khususnya negara berkembang dan negara masa transisi.

Prinsip-prinsip yang menyangkut hubungan manusia dengan lingkungan hidup, berhubungan satu sama lain dan menentukan warisan untuk generasi mendatang yaitu :

1. Kesehatan, pertanian organik harus melestarikan dan meningkatkan kesehatan tanah, tanaman, hewan, manusia dan bumi sebagai satu kesatuan yang tidak terpisahkan.

2. Ekologi, pertanian organik harus didasarkan pada sistem dan siklus ekologi kehidupan. Prinsip ekologi meletakkan pertanian organik dalam sistem ekologi kehidupan. Prinsip ini menyatakan bahwa produksi didasarkan pada proses dan daur ulang ekologis.

3. Keadilan, pertanian organik harus membangun hubungan yang mampu menjamin keadilan terkait dengan lingkungan dan kesempatan hidup bersama. Keadilan dicirikan dengan kesetaraan, saling menghormati, berkeadilan dan pengelolaan dunia secara bersama, baik antar manusia dan dalam hubungannya dengan makhluk hidup yang lain.

4. Perlindungan, pertanian organik harus dikelola secara hati-hati dan bertanggung jawab untuk melindungi kesehatan dan kesejahteraan generasi sekarang dan mendatang serta lingkungan hidup.

Faktor penunjang permintaan pertanian organik di negara-negara dipicu oleh:

1. Menguatnya kesadaran lingkungan dan gaya hidup alami dari masyarakat

2. Dukungan kebijakan pemerintah nasional

3. Dukungan industri pengolahan makanan

4. Dukungan pasar konvensional

5. Adanya kampanye nasional pertanian organik secara gencar

6. Pertanian organik memberikan jaminan akan kualitas tanah dan ekosistem lokal yang lebih baik

7. Menjaga kelestarian alam

\section{METODE PENELITIAN}

\section{Metode Penelitian}

Metode penelitian yang digunakan dalam penelitian ini adalah metode survei. Metode survei adalah metode penelitian yang mengambil sampel dari suatu populasi dan menggunakan kuesioner sebagai alat mengambil data pokok (Singarimbun, 1998). Survei ini dilakukan terhadap petani tentang sistem usaha tani. Dalam hal ini sampel tidak ditentukan dalam ukuran tertentu akan tetapi dengan metode snowball di mana peneliti merasa cukup atas informasi yang telah diberikan petani yang terpilih sebagai responden. Adapun data yang diperlukan terdiri dari jenis komoditi yang ditanam, luas lahan, penggunaan pupuk, pestisida, jumlah bibit, jumlah tenaga kerja, modal usaha, produksi dan pendapatan petani 


\section{Metode Analisis}

Metode analisis yang dipergunakan dalam penelitian ini adalah:

\section{Metode Deskriptif}

Metode deskriptif yaitu analisis yang dilakukan secara deskriptif terhadap variabel-variabel yang tidak bisa dikuantifikasi. Metode ini hanya merumuskan dan mengumpulkan data serta menginterprestasikan sehingga memberikan keterangan dari permasalahan yang ada. Masalahmasalah tersebut dianalisis dengan menggunakan teori yang terkait. Hal ini digunakan untuk menjelaskan kondisi pertanian yang sedang diusahakan petani.

\section{Fungsi Biaya Manfaat}

Perhitungan biaya manfaat di dapat dengan cara menghitung semua penerimaan yang diperoleh dari usaha tani dan menghitung semua biaya yang dikeluarkan. Biaya dimaksudkan adalah biaya yang digunakan dalam pengolahan usaha tani baik biaya tetap maupun biaya variabel.

Estimasi penerimaan dihitung dengan cara :

Keterangan :

$$
\mathbf{T R}=\mathbf{p} \times \mathbf{Q}
$$

$\mathrm{TR}=$ Total penerimaan

$\mathrm{p}=$ Harga

$\mathrm{Q}=$ Jumlah barang yang dijual

Estimasi biaya dihitung dengan cara :

Keterangan :

$$
\mathbf{T C}=\mathbf{F C}+\mathbf{V C}
$$

$\mathrm{TC}=$ Total Biaya

$\mathrm{FC}=$ Biaya Tetap

$\mathrm{VC}=$ Biaya Variabel

\section{Analisis Kelayakan Usaha}

Metode kuantitatif menggunakan analisis kelayakan usaha. Hal ini berhubungan dengan bagaimana menilai kelayakan usaha dengan pola pertanian organik. Analisis usaha yang dilakukan adalah :

\section{a. Laba Rugi}

Keuntungan $=$ Total Penerimaan - Total Biaya

$$
=\left(\begin{array}{lll}
p & x & Q
\end{array}\right)-(F C+V C)
$$

\section{b. Return Cost Ratio}

$R / C=$ Total penerimaan penjualan produk / total biaya

\section{c. Benefit Cost Ratio}

$B / C=$ Tingkat keuntungan / total biaya

d. Break Event Point (BEP)

BEP produksi $=$ Total Biaya $/$ Harga Penjualan

$B E P$ harga $=$ Total Biaya $/$ Total Produksi

\section{PEMBAHASAN}

Penggunaan pupuk dan bahan kimia sebagai faktor produksi sebaiknya mulai dikurangi untuk kemudian digantikan oleh pupuk organik, pupuk hayati dan pestisida nabati. Pupuk organik dapat berupa kompos (alam atau buatan), pupuk kandang atau pupuk hijau. Pupuk hayati merupakan kultur mikroorganisme yang sudah teruji mempunyai peran istimewa dalam meningkatkan kesuburan tanah atau tanaman. 
Trend pertanian organik juga sedang mewabah sekarang ini. Produk organik diberi nilai lebih oleh konsumen, tentu saja dengan harga yang lebih tinggi dan lebih mudah diterima masyarakat internasional. Pertanian organik lebih cenderung lebih ramah lingkungan karena bersifat spesific local.

Di kecamatan Maro Sebo pertanian organik masih belum dikembangkan. Petani lebih cenderung menggunakan pupuk kimia bahkan ada yang tidak menggunakan pupuk dalam usaha tani. Potensi lahan yang masih subur mendorong petani tidak banyak menggunakan pupuk kimia maupun pupuk organik buatan, karena produksi pertanian masih dirasa cukup menguntungkan. Di samping itu pola pertanian yang diterapkan petani sebagian besar khususnya masyarakat lokal bukan warga eks transmigrasi masih bersifat tradisional di mana sistem pertanian masih belum begitu mengenal teknologi.

\section{Potensi Bidang Pertanian Tanaman Pangan dan Holtikultura}

Luas lahan di kabupaten Muaro Jambi pada tahun 2015 seluas 436.879 hektar, terdiri dari lahan sawah 24.818 hektar, pertanian bukan sawah 353.519 hektar dan bukan pertanian 58.842 hektar. Hal ini menunjukkan bahwa kabupaten Muaro Jambi merupakan wilayah potensi tanaman pangan. Komoditas pertanian tanaman pangan kabupaten Muaro Jambi adalah padi, jagung, ubi kayu, kacang kedelai, kacang hijau dan umbi-umbian lainnya.

Mengingat letak geografis, maka Kumpeh dan Maro Sebo lebih diarahkan sebagai sentra produksi pertanian lahan kering skala kabupaten, yang diharapkan dapat memenuhi kebutuhan penduduk di dalam wilayah Kabupaten Muaro Jambi. Ciri khas dari pertanian hortikultura ini adalah tanaman lahan kering yang bernilai ekonomi tinggi (Tejoyuwono, 1989), seperti sayur-sayuran. Komoditas pertanian hortikultura yang dapat dikembangkan di Muaro Jambi adalah kembang kol,kentang, kubis, wortel, labu siam, bawang daun, sawi, buncis dan cabe. Sebagian besar Mengingat karakteristik wilayah dan penduduk serta kesesuaian lahan yang ada, maka kawasan yang diarahkan sebagai kawasan pengembangan pertanian holtikultura dengan kawasan inti Kecamatan Kumpeh dan Kecamatan Maro Sebo.

Selain itu tanaman buah-buahan dan sayur-sayuran cukup berlimpah dan berkembang sejalan dengan kebutuhan masyarakat. Sedangkan untuk buah-buahan telah dikembangkan beraneka jenis buah-buahan tropis seperti duku, pisang, nanas, jeruk manis, nangka dan sebagainya.

Ditinjau dari produktivitas lahan untuk komoditi padi dan padi ladang produktivitas lahan di kabupaten Muaro Jambi lebih rendah dibandingkan dengan provinsi secara keseluruhan. Namun demikian untuk komoditi cabe, jagung, ubi kayu, ubi jalar dan kacang tanah produktivitas lahan di kabupaten Muaro Jambi lebih tinggi dari pada produktivitas lahan provinsi Jambi.

\section{Analisis Pertanian Padi Sawah}

Padi dapat tumbuh pada ketinggian $0-1.500 \mathrm{~m}$ dpl dengan temperatur $19-27^{\circ} \mathrm{C}$, memerlukan penyinaran matahari penuh tanpa naungan. Angin berpengaruh pada penyerbukan dan pembuahan. Padi menghendaki tanah lumpur yang subur dengan ketebalan $18-22 \mathrm{~cm}$ dan $\mathrm{pH}$ tanah 4 - 7. Kecamatan Maro Sebo sangat memungkinkan 
pengembangan komoditi padi baik untuk padi sawah maupun padi ladang dengan potensi lahan yang masih luas.

\section{Kelayakan usaha padi dengan sistem organik \\ Asumsi}

1) Petani pemilik lahan

2) Petani bukan pemilik lahan pola bagi hasil 1 : 3 ( I bagian untuk pemilik lahan dan 2 bagian dari hasil merupakan bagian untuk petani penggarap)

3) Luas lahan yang digarap 1 hektar

4) Lahan yang digarap bukan merupakan pembukaan lahan baru

5) Menggunakan bibit unggul

6) Masa tanam hingga panen 4 bulan

7) Produktivitas lahan 5 ton gabah per hektar atau 3,5 ton beras

8) Harga jual gabah kering Rp 6.500/kg atau dalam bentuk beras dengan harga jual $\mathrm{Rp} 10.000 / \mathrm{kg}$

9) Penggunaan hanya pada pupuk organik sedangkan obat pestisida belum dapat menggunakan pestisida organik

\section{Investasi \\ 1) Membersihkan lahan \\ 2) Penyiapan bibit}

\section{Biaya Operasional}

1) Biaya bibit 10 kotak @ Rp 35.000,-

2) Biaya tenaga kerja 5 orang x 120 hari@ Rp 25.000,-

3) Biaya obat-obatan dan pemupukan

4) Biaya lain-lain
$\operatorname{Rp} 1.500 .000,-$

Rp1.800.000,-

Rp 350.000,-

Rp 15.000.000,-

Rp 500.000,-

$\underline{\mathrm{Rp} 500.000,-}$

Rp16.350.000,-

\section{Penerimaan}

1) Produksi 5 ton gabah @ Rp 6.500,-/kg Rp 32.500.000,-

2) Produksi 3,5 ton beras @ Rp 10.000,-/kg Rp 35.000.000,-

\section{Analisis Usaha bila produksi dalam bentuk gabah}
1) Laba Rugi
2) Return Cost Ratio (R/C)
3) Benefit Cost Ratio (B/C)
1,79
4) Break Event Point (BEP) Produksi
0,79
$3.630 \mathrm{~kg}$
5) Break Event Point (BEP) Harga
Rp 2.792

Rp 14.350.000,

Analisis Usaha bila produksi dalam bentuk beras

1) Laba Rugi

2) Return Cost Ratio (R/C)

Rp 16.850.000,-

3) Benefit Cost Ratio (B/C)

1,92

0,92

4) Break Event Point (BEP) Produksi

$4.840 \mathrm{~kg}$

5) Break Event Point (BEP) Harga

Rp 1.815

Analisis ini menunjukkan bahwa keuntungan yang diperoleh dari pertanian sebesar Rp 14.350.000,- bila produksi dalam bentuk gabah. Sedangkan produksi dalam bentuk beras akan memperoleh keuntungan sebesar Rp 16.850.000,- dengan menambah biaya giling sebesar Rp 2.500.000,-. Dari indikator kelayakan usaha secara umum pertanian 
organik untuk komoditi padi masih menguntungkan. Pada petani yang menggunakan lahan orang lain maka akan ada bagi hasil untuk pemilik lahan.

\section{Analisis Usaha Pertanian Jagung}

Jagung merupakan komoditi tanaman pangan penting, namun tingkat produksi belum optimal. Jagung tidak memerlukan persyaratan khusus, namun tanah yang gembur, subur dan kaya humus akan berproduksi optimal.

\section{Kelayakan usaha jagung dengan sistem organik}

\section{Asumsi}

1) Petani pemilik lahan

2) Petani bukan pemilik lahan pola bagi hasil 1 : 3 ( I bagian untuk pemilik lahan dan 2 bagian dari hasil merupakan bagian untuk petani penggarap)

3) Luas lahan yang digarap 1 hektar

4) Lahan yang digarap bukan merupakan pembukaan lahan baru

5) Menggunakan bibit unggul

6) Masa tanam hingga panen 3 bulan

7) Produktivitas lahan 4 ton per hektar

8) Harga jual jagung kering Rp 3.000/kg

Investasi
1) Membersihkan lahan
2) Lobang tanaman
Rp 1.500.000,-
Rp 350.000,-
Rp 1.850.000,-

\section{Biaya Operasional}
1) Biaya bibit 10 kotak @ Rp Rp 300.000,- 30.000,-
2) Biaya tenaga kerja 2 orang $x \quad R p$ 6.300.000,- 90 hari@ Rp 35.000,-
3) Biaya obat-obatan
4) Biaya lain-lain
Rp 500.000,- Rp 600.000,--
Rp7.700.000,-

\section{Penerimaan}

1) Produksi 4.250 @ Rp 3.000,- $\quad R p$ 12.750.000,-

\section{Analisis Usaha}
1) Laba Rugi
2) Return Cost Ratio (R/C)
Rp 3.200.000,-
3) Benefit Cost Ratio (B/C)
1,33
0,33
4) Break Event Point (BEP) $2.247 \mathrm{~kg}$ Produksi

Analisis kelayakan usaha menunjukkan keuntungan yang diperoleh sebesar Rp 3.200.000,- pada tingkat $\mathrm{B} / \mathrm{C}=0,33$

\section{Analisis Usaha Pertanian Cabai}

Cabai dapat ditanam di dataran tinggi maupun rendah, $\mathrm{pH}$ 5-6. Bertanam cabai dihadapkan dengan berbagai masalah (resiko), diantaranya teknis budaya, kekurangan unsur, serangan hama dan penyakit. Petani cabai menyebar hampir di seluruh desa dengan pola tanam yang beragam mulai dari yang tradisional, semi intensif dan bahkan intensif yang secara umum menggunakan pupuk unorganik. Pupuk organik yang digunakan sebagian besar masih sebatas pupuk kandang. 


\section{Kelayakan usaha cabai dengan sistem organik \\ Asumsi}

1) Petani pemilik lahan

2) Petani bukan pemilik lahan pola bagi hasil 1 : 3 ( I bagian untuk pemilik lahan dan 2 bagian dari hasil merupakan bagian untuk petani penggarap)

3) Luas lahan yang digarap 1 hektar

4) Lahan yang digarap bukan merupakan pembukaan lahan baru

5) Menggunakan bibit unggul

6) Masa tanam hingga panen 4 bulan

7) Produktivitas lahan 6 ton hektar

8) Harga jual cabai $\mathrm{Rp} 15.000,-/ \mathrm{kg}$

Investasi
1) Membersihkan lahan
Rp 1.500.000,-
2) Galangan
3) Plastik
Rp 1.500.000,-
Rp 300.000,-
Rp 3.300.000,-

\section{Biaya Operasional}
1) Biaya bibit 10 kotak @ Rp Rp 900.000,- 90.000,- Rp12.600.000,-
2) Biaya tenaga kerja 3 orang $x$ 120 hari@Rp 35.000,-
3) Biaya obat-obatan
4) Biaya lain-lain
Rp 5.000.000,-
Rp 1.000.000,-
Rp19.500.000,-

Penerimaan

1) Produksi $250 \mathrm{~kg}$ setiap kali panen panen sebanyak 20 kali Rp 75.000.000,-

2) Harga Rp $15.000 / \mathrm{kg}$

\section{Analisis Usaha}

1) Laba Rugi

2) Return Cost Ratio (R/C)

Rp 52.200.000,-

3) Benefit Cost Ratio (B/C)

3,28

4) Break Event Point (BEP) $4.560 \mathrm{~kg}$

Produksi

5) Break Event Point (BEP) Harga

Usaha komoditi pertanian cabai lebih menguntungkan dari pada menanam padi maupun jagung. Keuntungan usaha sebesar Rp52.200.000,selama 4 bulan pada tingkat $\mathrm{B} / \mathrm{C}=2,28$. Namun demikian resiko kegagalan cukup besar pada petani baik disebabkan oleh hama penyakit maupun aspek pasar karena harga yang berfluktuasi.

\section{SIMPULAN}

Dari pembahasan yang telah dilakukan diketahui bahwa:

1. Sektor pertanian masih merupakan sektor utama dalam mendukung perekonomian kabupaten Muaro Jambi. Sentra pertanian khususnya sayursayuran dan buah-buahan banyak terdapat di dua kecamatan yaitu kecamatan Kumpeh dan kecamatan Maro Sebo.

2. Analisis kelayakan usaha dari tiga komoditi terpilih untuk usaha pertanian organik yaitu padi, jagung dan cabe mampu memberikan keuntungan yang cukup besar bagi petani. Hal ini menunjukkan usaha 
pertanian organik secara khusus untuk tiga komoditi tersebut secara finansial layak diusahakan.

3. Aspek pasar di tingkat lokal atau pasar utama penjualan produksi pertanian dari Maro Sebo ke kota Jambi memang belum terlihat adanya segmen khusus yang memisahkan produk pertanian anorganik dan pasar produk pertanian organik

\section{DAFTAR PUSTAKA}

Go Organik 2010 sumber website : http://www.beritabumi.or.id Mubyarto, 1998. Penghantar Ekonomi Pertanian LP3ES. Jakarta

Singarimbun, Masri dan S. Efendi, 1998. Metode Penelitian Survey, LP3ES. Jakarta

Standar Pertanian Organik Indonesia, sumber website : www.jakerpo.org diterbitkan oleh Jaringan Kerja Pertanian Organik Indonesia (Jaker PO Indonesia)

Sukartawi. 1990. Teori Ekonomi Produksi, Rajawali Pers. Jakarta

Sukirno, Sadono. 2011. Mikro Ekonomi PT. Raja Grafindo Persada. Jakarta.

Todaro, Michael P. Dan Stephen C. Smith, 2006. Pembangunan Ekonomi, Edisi Kesembilan. Erlangga, Jakarta.

http://Indonesia-agriculture.com Teknik Budidaya Agrokomplek 